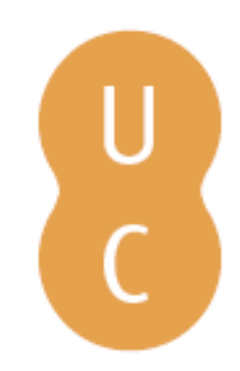

pnmbalina

\title{
Monitoring erosion risk with ERMIT model: a case study in North Sardinia, Italy
}

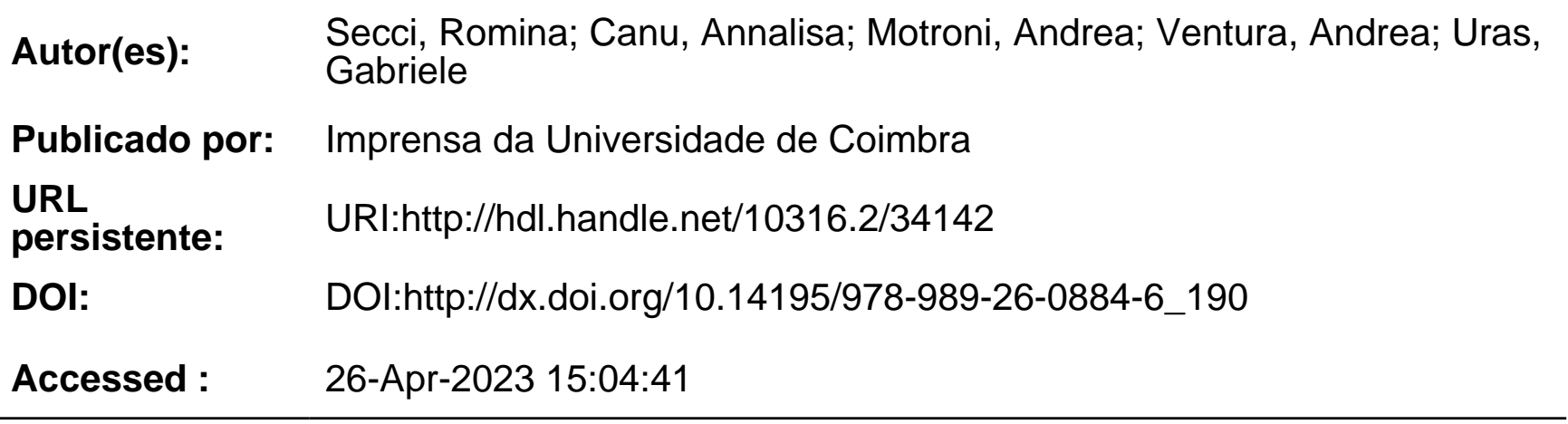

A navegação consulta e descarregamento dos títulos inseridos nas Bibliotecas Digitais UC Digitalis, UC Pombalina e UC Impactum, pressupõem a aceitação plena e sem reservas dos Termos e Condições de Uso destas Bibliotecas Digitais, disponíveis em https://digitalis.uc.pt/pt-pt/termos.

Conforme exposto nos referidos Termos e Condições de Uso, o descarregamento de títulos de acesso restrito requer uma licença válida de autorização devendo o utilizador aceder ao(s) documento(s) a partir de um endereço de IP da instituição detentora da supramencionada licença.

Ao utilizador é apenas permitido o descarregamento para uso pessoal, pelo que o emprego do(s) título(s) descarregado(s) para outro fim, designadamente comercial, carece de autorização do respetivo autor ou editor da obra.

Na medida em que todas as obras da UC Digitalis se encontram protegidas pelo Código do Direito de Autor e Direitos Conexos e demais legislação aplicável, toda a cópia, parcial ou total, deste documento, nos casos em que é legalmente admitida, deverá conter ou fazer-se acompanhar por este aviso.

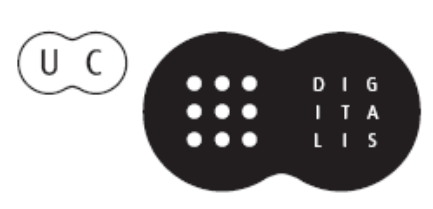




\section{ADVANCES IN}

Forest Fire

\section{RESEARCH}

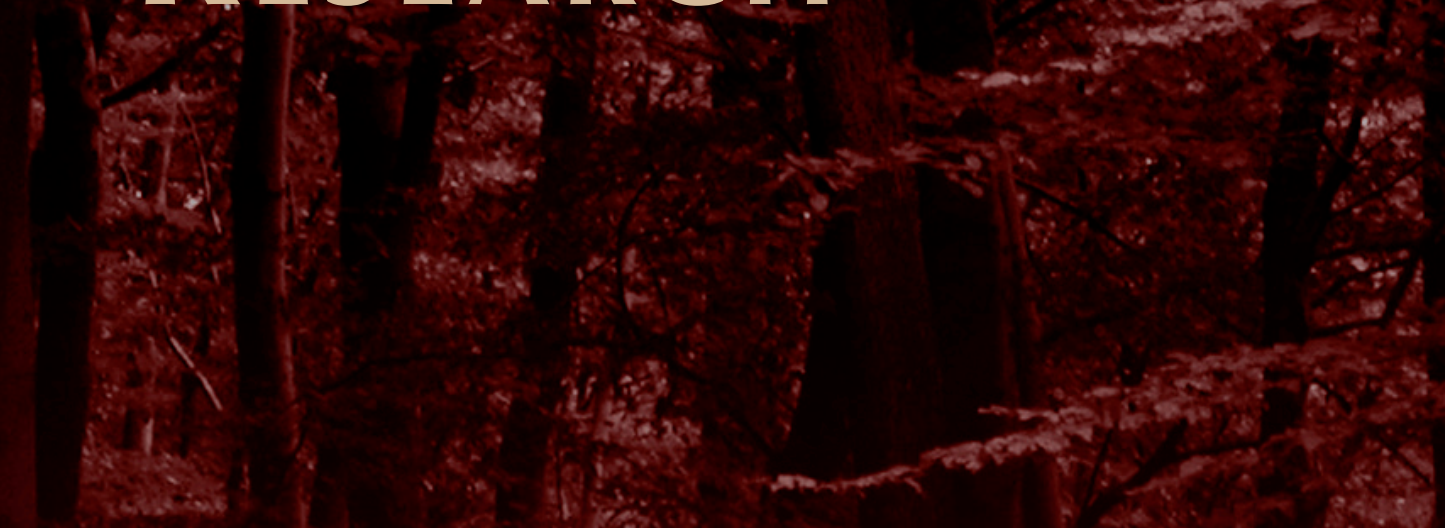

\section{DOMINGOS XAVIER VIEGAS}

\section{EDITOR}




\title{
Monitoring erosion risk with ERMIT model: a case study in North Sardinia, Italy
}

\author{
Romina Secci ${ }^{\mathrm{a}}$, Annalisa Canu $^{\mathrm{b}}$, Andrea Motroni $^{\mathrm{c}}$, Andrea Ventura $^{\mathrm{b}}$, Gabriele Uras ${ }^{\mathrm{a}}$ \\ ${ }^{a}$ University of Cagliari, DICAAR, romysecci@gmail.com \\ ${ }^{b}$ CNR - IBIMET Sassari, canu@ibimet.cnr.it \\ ${ }^{c}$ ARPAS - Meteo-Climatic Department, amotroni@arpa.sardegna.it
}

\begin{abstract}
Wildfires are one of the most widespread factors of ecosystem degradation around the world. The present note reports the first experimental results of a wider-scale research project, whose aim is to develop methods for the analysis and the collection of field data, by means of a multidisciplinary approach, to evaluate land erosion hazard.

The experimental area is located in Mediterranean basin, on a steep slope in a hilly area of north-western Sardinia (Municipality of Ittiri, Italy), where a human caused fire occurred in August 2013. The area is mainly covered by the typical Mediterranean vegetation. The forest fire spread through the study area in August 2013 and the burn severity has been moderate, according to USDA burn severity classification system. After the fire, sediment fences were installed to trap sediments eroded by natural rainfall. Precipitations were recorded using tipping bucket rain gauge installed at the site.

Soil erosion rates from experimental plots were measured and estimated with silt fences technique taking into account different slopes and vegetation distribution. The study aims to compare the results obtained by ERMIT (Erosion Risk Management Tool) model application and post-fire sediment yields measured in the study area. The application of the model shows that the area experienced most of erosion after the first rain events after fire occurring. Comparing experimental and model estimated data, there is evidence of ERMiT model overestimating in respect of sampled data for the first year. Future experimental data are needed to confirm this assumption and to contribute to calibrate ERMiT in a Mediterranean typical vegetation and climate environment.
\end{abstract}

Keywords: erosion risk, ERMIT, burned area, forest fire effects

\section{Introduction}

Several authors suggest that in the early months following the passage of a fire, the soil erosion increases dramatically (DeBano et al., 1998; Campo et al., 2006), even if gaps and further investigation in this field can be easily outlined and recommended (Shakesby, 2011). High soil temperatures can increase the erodibility of the soil surface, giving an indication of the susceptibility of the soil to the impact of raindrops, to runoff, and other erosive processes (Moody and Martin 2009, Scott et al., 2009). In extreme situations, burned areas of unstructured soils may be interested by processes of waterproofing and soils becoming hydrophobic (Imeson et al., 1992). Available sediment can be eroded from slopes and channels, transported and deposited downward in the valley driven by erosion energetic inputs: precipitation, runoff, wind, and gravity. The loss of vegetation and forestry sediments increase surface runoff in sloppy areas because longer flow paths are formed without interruption, without surface roughness, and because the wind speed increase. These changes increase the amount of energy available for erosion and sediment transport (Moody and Martin 2009a). The effects of fire on hydrology can be mitigated by the presence of ash: forest fires can leave a dry, porous layer of ash that covers the mineral soil (Cerdà and Robichaud, 2009).

The increase of landslide phenomena in slope areas crossed by forest fires, is well documented in the scientific literature (Curran et al. 2006; DeBano et al. 1998; Lane et al. 2006; Moody et al. 2009; 
Neary et al. 2005). In general, the hydrological response at the catchment scale is inversely correlated to the effectiveness of the after fires treatment (Robichaud et al. 2008).

ERMiT is a web-based application developed by USDA (Robichaud, 2007a) that uses Water Erosion Prediction Project (WEPP) technology to estimate soil erosion, in probabilistic terms, on burned lands with and without the application of erosion mitigation treatments. Data inputs are: climate parameters, vegetation type, soil type, topography, and soil burn severity class. The above parameters were applied to the ERMIT model and it was possible to predict the probably erosion risk for the next 5 years.

The objective of this work is to show preliminary results of erosion sediments yield in a hilly burned area of north-western Sardinia (Italy) and the correspondent output data from the application of ERMiT model.

\section{Methods}

\subsection{Study site and data collection}

The experimental area is located in a hilly area of north-western Sardinia, (around urban area of Sassari, Italy, 40 $33^{\prime} \mathrm{N}$; $8^{\circ} 31^{\prime} \mathrm{E}$ ), where a human caused fire occurred in August 2013 and burned an area of 28 hectares (Figure 1). The area is mainly covered by typical Mediterranean chaparral vegetation.

The climate is typically Mediterranean with water deficit conditions occurring from May through September and precipitations mainly concentrated in autumn and winter.

The mean annual rainfall is $730 \mathrm{~mm}$ and annual mean air temperature is $16.8{ }^{\circ} \mathrm{C}$. Most fires occur during the summer season, from June to September.

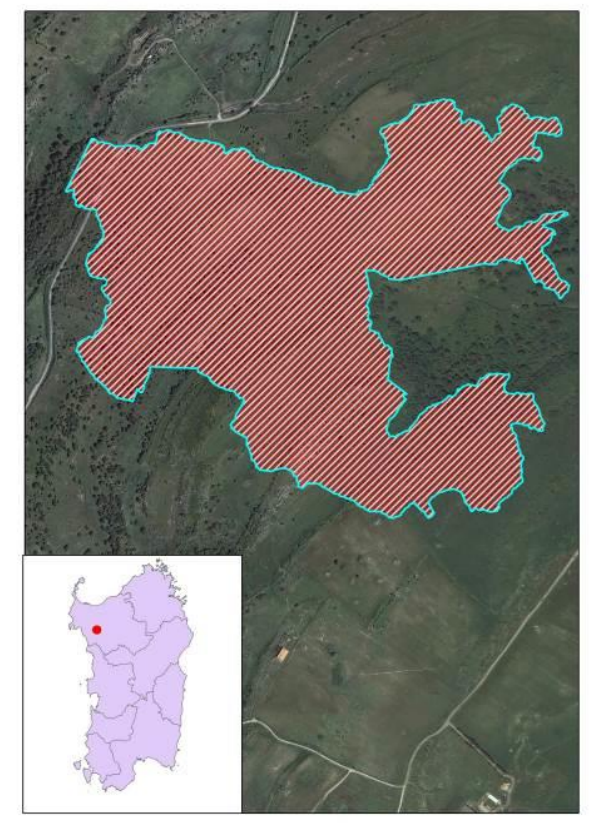

Figure 1. Study area and perimeter of burned area

In August 2014, sediment fences were installed in 10 plots in an area with a slope of $20 \%$ to capture sediment produced by natural rainfall (Robichaud and Brown, 2002).

\subsection{ERMIT model}

ERMiT (Erosion Risk Management Tool) is a web-based application that uses Water Erosion Prediction Project (WEPP) technology to estimate erosion in probabilistic terms, on burned and recovering forest, range, and chaparral lands with and without the application of erosion mitigation treatments. User inputs are processed by ERMiT to combine rain event variability with spatial and 
temporal variabilities of soil burn severity and soil properties, which are then used as WEPP input parameters. ERMiT produces a distribution of rain event sediment delivery rates with a probability of occurrence for each of five post-fire years. In addition, event sediment delivery rate distributions are generated for post-fire hillslopes that have been treated with seeding, straw mulch, and erosion barriers such as contour-felled logs or straw wattles. In this work for every simulation has been considered only the results of the untreated hillslope.

User inputs for ERMiT are climate, soil texture, soil rock content, vegetation type (forest, range, chaparral), hillslope gradient and horizontal length, soil burn severity class for range and chaparral, and pre-fire plant community description (relative distribution of shrub, grass, and soil cover in percentages). User inputs are entered on a single interactive browser screen. ERMiT's "event sediment delivery exceedance probability" output can help managers to decide where, when, and how to apply treatments to mitigate the impacts of post-wildfire runoff and erosion on life, property, and natural resources. With ERMiT, managers can establish a maximum acceptable event sediment yield and use ERMiT to determine the probability of "higher than acceptable" sediment yields occurring (Robichaud, 2007b).

Simulations were carried out for the burned area taking into consideration the same input parameters for all the runs. The only change was made for the vegetation values immediately and 6 months after fire occurring. Successive validation of ERMiT was completed with field data.

Hill slope burned area was divided in 10 plots $(10 \mathrm{~m} \times 3 \mathrm{~m})$ limited in the downhill edge by silt fences in order to contain eroded soil and debris of each specific plot. Silt fences used in this study are easy to be installed and costless (Robichaud and Brown, 2002), being made of wooden posts and geotextile fabric (figure 2). Eroded material is collected, weighted and analysed possibly soon after the major rain events.
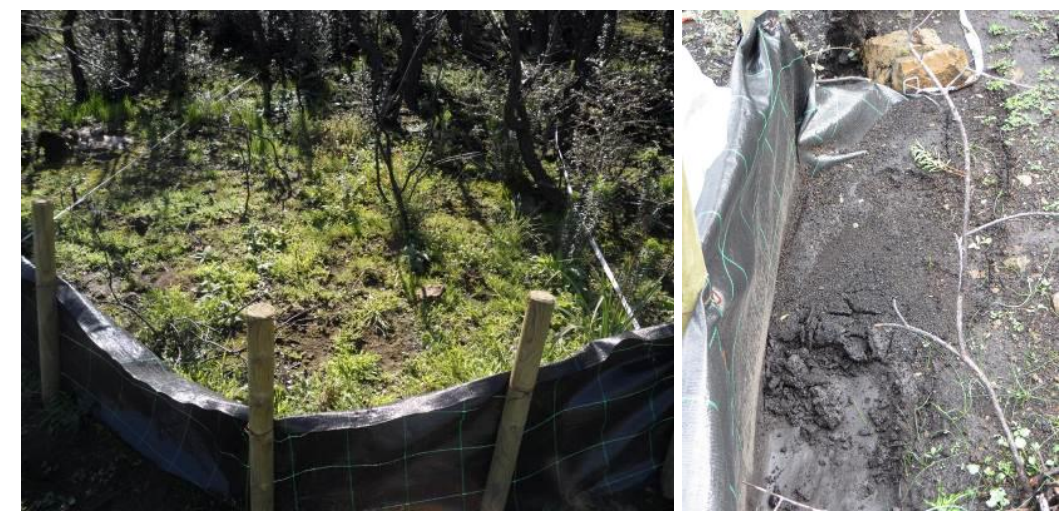

Figure 2. Example of sample plot and sediment trapped in the silt fence

\subsubsection{Climate parameters}

Climatic data for ERMiT simulations referred to the closest weather station of Hydrological Department of Sardinia. Temperature and precipitation data series for the period 1988-2002 were considered. In ERMiT simulation runs, the monthly means of rainfall and the number of rainy days for each month of the year are considered. Mean, maximum and minimum temperature values were also input data for modeling.

\subsubsection{Vegetation}

Prevailing surrounding vegetation is Mediterranean chaparral in garrigue association, while as the areas where fire occurred is dominated by oak tree (Quercus suber spp.) forest. Ground cover ocular estimation (percentage of herbaceous, bare soil and stoniness surface) were made using a $1 \mathrm{~m}^{2}$ point frame with wire intersections at $10 \mathrm{~cm}$ intervals (figure 3 ) with 3 repetitions per plot. 
Vegetation cover measurements were made both soon after fire occurring in late August 2013 and in early days of May 2014, so after about 8 months. In this way different recovering attitudes and characteristics of the plots inside the area were considered.

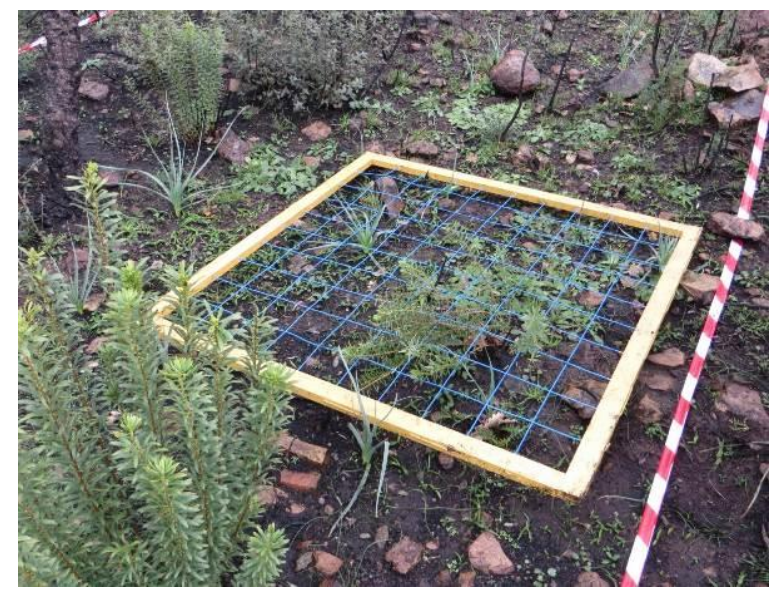

Figure 3. Vegetation cover measurement

\subsubsection{Type of soil}

Several soil samples were collected at $0-10 \mathrm{~cm}$ depth, in burned plots. Analysis were performed in collaboration with the Geotechnical laboratory of Cagliari Province. Two trials of texture repetitions were conducted considering both sieving (for $0.075 \div 100 \mathrm{~mm}$ grains) and sedimentation $(0.0055 \div 0.1117 \mathrm{~mm}$ grains $)$. Results are shown in table 1 . Soil is therefore constituted mostly by sand and clay.

Table 1. Basic statistics for each soil property

\begin{tabular}{|c|c|c|c|c|c|c|c|c|c|c|c|c|}
\hline & $\mathrm{pH}$ & $\mathrm{Ng} \mathrm{Kg}^{-1}$ & & & $\mathrm{P}_{2} \mathrm{O}_{5} \mathrm{ppm}$ & Silt \% & Clay \% & Sand \% & $2 \mathrm{~mm} \%$ & $\mathrm{~mm} \%$ & $0,5 \mathrm{~mm} \%$ & $\mathrm{~nm} \%$ \\
\hline mean & 6,36 & & 3,68 & 3,70 & 12,86 & 26,13 & 26,61 & 47,26 & 31,76 & 2,21 & 1,41 & 3, \\
\hline st. dev. & 0,11 & & 1,23 & 0,21 & 1,87 & 4,61 & 7,18 & 3,40 & 9,78 & 0,79 & 0,56 & 0, \\
\hline
\end{tabular}

\subsubsection{Slope}

Slope was measured in the field using a digital level instrument (Stabila 86 Electronics). Several measures were made for each plot and the average slope was considered (20\% in this case).

\subsubsection{Soil burn severity}

Burn severity was estimated applying USDA methodology as reported in the "Field guide for mapping soil burn severity" (Parsons et al., 2010). Ocular estimation of fire severity and damages caused by burning and the comparison with clear pictures of similar situations allows to have a fast, reasonably precise classification of burn severity. The severity of the fire was considered "moderate" based on post fire analysis and vegetation recovering capacity, together with vegetation damages and limited infiltration rates of topsoil.

\section{Results}

Figure 4 shows the daily cumulative, maximum intensity 30 minute rainfall ( $\left.\mathrm{I}_{30} \max \right)$ and the sample dates. The total precipitation recorded in the period September 2013 - April $2014(653 \mathrm{~mm})$ is about $90 \%$ of the mean annual rainfall. Four periods of sediment accumulation were carried out during the 
experimentation, and sediments were removed from the silt fence on 10 September 2013, 29 January, 19 March, and 10 April 2014. These dates are reported in the figure 4 in black (sample).

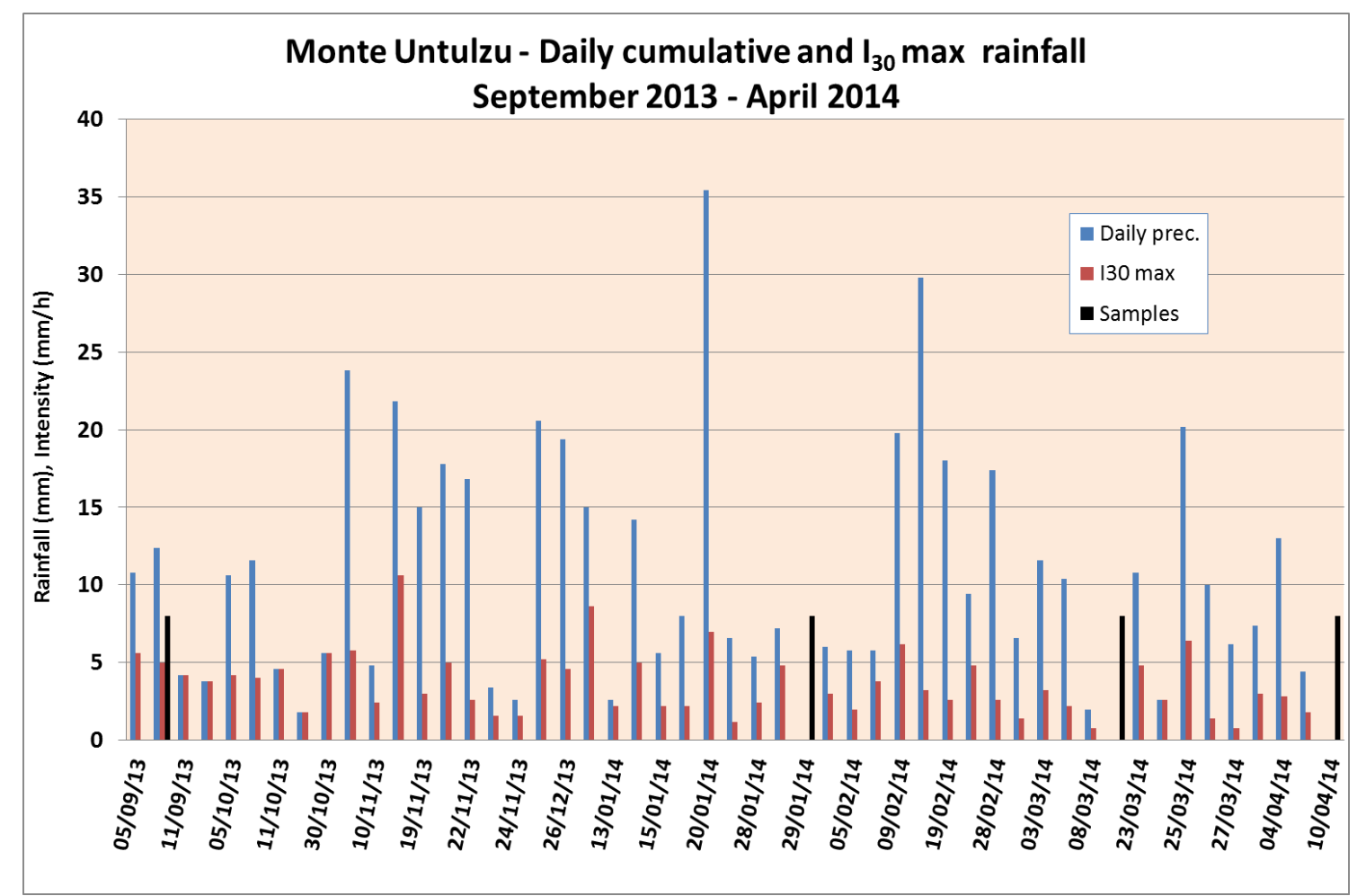

Figure 4. Daily cumulative rainfall and $I_{30} \max$

Mean values of measured soil loss for each sample of plots with slope of $20 \%$ are reported in figure 5 . The highest erosion was observed in the first sample $\left(1.6 \mathrm{t} \mathrm{ha}^{-1}\right)$, whereas, in the last sample, event erosion rate was very low, only $0.02 \mathrm{t} \mathrm{ha}^{-1}$.

Total soil erosion loss recorded during this study was $2.8 \mathrm{t} \mathrm{ha}^{-1}$. Vacca et al. (2000) had much lower results in erosion plots under burned chaparral in southern Sardinia $\left(0.51-0.26 \mathrm{t} \mathrm{ha}^{-1}\right)$; even lower sediment values $\left(0.014 \mathrm{t} \mathrm{ha}^{-1}\right)$ were recorded in Bonassai, northwestern of Sardinia, on burned pasture (Rivoira et al., 1989) this low values are probably due to the low severity of fire.

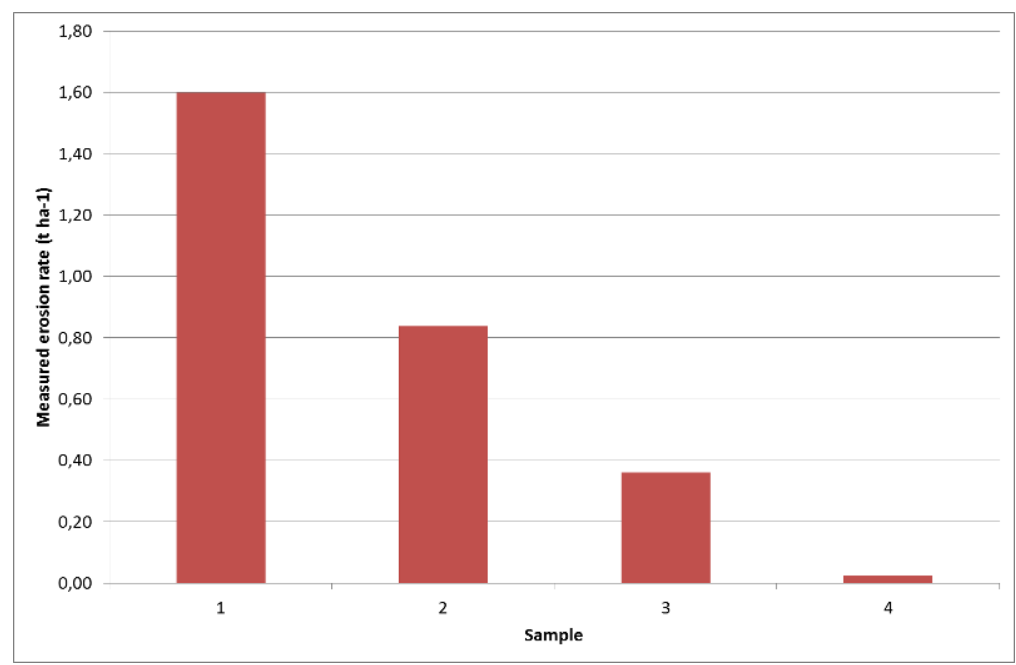

Figure 5. Mean values of measured soil loss $\left(\mathrm{t} \mathrm{ha} \mathrm{h}^{-1}\right)$ 
The results of ERMiT simulations are shown in figures 6 and 7. Only untreated estimates were considered with different probability that sediment yield will exceed a certain threshold. Soil losses estimated by ERMiT for the first year are 3.23 and $3.13 \mathrm{t} \mathrm{ha}^{-1}$, soon after fire and six months after fire, respectively.

Model results compared with the field measurements show how ERMIT model tends to overestimate erosion rates in typical Mediterranean vegetation and soil conditions. These preliminary results need to be confirmed by further investigation in coming years and also in different sites with similar vegetation, slope and soil conditions, given a defined fire severity and precipitation patterns.

\begin{tabular}{|c|c|c|c|c|c|}
\hline \multicolumn{6}{|c|}{ Sediment Delivery } \\
\hline \multirow{2}{*}{$\begin{array}{l}\text { Probability that } \\
\text { sediment yield } \\
\text { will be exceeded }\end{array}$} & \multicolumn{5}{|c|}{$\boxminus$ Event sediment delivery (t ha ${ }^{-1}$ ) $\boxminus$} \\
\hline & \multicolumn{5}{|c|}{ Year following fire } \\
\hline $\begin{array}{ll}20 & 90\end{array}$ & 1st year & 2nd year & 3 rd year & 4th year & 5th year \\
\hline Untreated $\square$ & 3.23 & 1.66 & 0.7 & 0.6 & 0.5 \\
\hline Seeding 믐 & 3.23 & 0.9 & 0.6 & 0.5 & 0.5 \\
\hline Mulch $\left(1 \mathrm{t} \mathrm{ha}^{-1}\right) \square$ & 0.7 & 0.7 & 0.7 & 0.6 & 0.5 \\
\hline Mulch $\left(2 \mathrm{tha}^{-1}\right)$ 可 & 0.6 & 0.6 & 0.7 & 0.6 & 0.5 \\
\hline Mulch $\left(3.5 \mathrm{t} \mathrm{ha}^{-1}\right)$ 昌 & 0.58 & 0.6 & 0.7 & 0.6 & 0.5 \\
\hline Mulch $\left(4.5 \mathrm{t} \mathrm{ha}^{-1}\right) \square$ & 0.56 & 0.6 & 0.7 & 0.6 & 0.5 \\
\hline \multicolumn{2}{|c|}{ Erosion Barriers: Diameter 0} & \multicolumn{2}{|c|}{ m Spacing 50} & $\mathrm{~m} 90$ ? & \\
\hline Logs \& Wattles & 3.23 & 1.66 & 0.7 & 0.6 & 0.5 \\
\hline
\end{tabular}

Figure 6. Example of ERMiT output of sediment delivery $20 \%$ exceedance probability

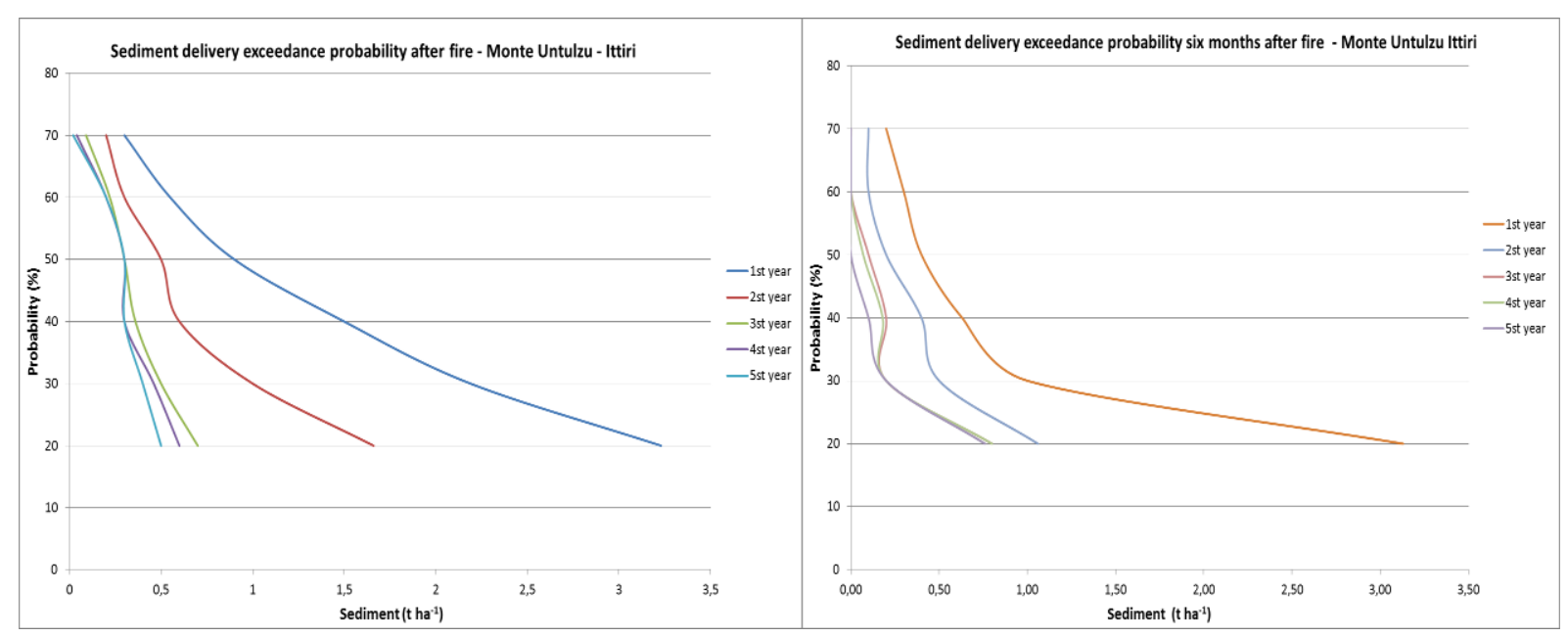

Figure 7. Exceedance probability vs event sediment delivery for five years after the fire(left) and after six months in the study area (right)

\section{References}

Campo, J.; Andreu, V.; Gimeno-García, E.; González, O.; Rubio, J.L.; 2006. The occurrence of soil erosion after repeated experimental fires in a Mediterranean environment, Geomorphology vol 82, n. 3-4, 376- 387.

Cerdà, A.; Robichaud, P.R., eds. Fire effects on soils and restoration strategies., 2009, Enfield, NH, USA, Science Publishers. pp. 589. 
Curran, M.; Chapman, B.; Hope, G.; Scott, D. 2006. Large-scale erosion and flooding after wildfires: understanding the soil conditions. B.C. Tech. Rep. 030. Victoria, B.C. Canada: B.C. Ministry of Forests and Range, Research Branch. 18 p.

DeBano, L.; Neary, D.; Folliott, P. 1998. Fire's effects on ecosystems. New York, NY: John Wiley \& Sons. 333 p.

Imeson, A.C. ; Verstraten, J.M.; van Mulligen, E.J.; Sevink, J.; 1992, The effects of fire and water repellency on infiltration and runoff under Mediterranean type forest, Catena, 19: 345-361.

Lane, P.N.J.; Sheridan, G.J.; Noske, P.J. 2006. Changes in sediment loads and discharge from small mountain catchments following wildfire in south eastern Australia. Journal of Hydrology. 331: 495510.

Moody, J. A.; Martin, D. A.; 2009. Synthesis of sediment yields after wildland fire in different rainfall regimes in the western United States, International Journal of Wildland Fire 18(1) 96-115 http://dx.doi.org/10.1071/WF07162.

Neary, Daniel G.; Ryan, Kevin C.; DeBano, L. F.; eds. 2005. (revised 2008). Wildland fire in ecosystems: effects of fire on soils and water. Gen. Tech. Rep. RMRS-GTR-42-vol. 4. Odgen, UT: U.S. Department of Agriculture, Forest Service, Rocky Mountain Research Station. 250 p.

Parsons, A., Robichaud, P.R., Lewis, S.A., Napper, C., Clark, J.T. 2010. Field guide for mapping postfire soil burn severity. Gen. Tech. Rep. RMRS-GTR-243. Fort Collins, CO: U.S. Department of Agriculture, Forest Service, Rocky Mountain Research Station. 49 p.

Rivoira, G.; Roggero, PP.; Bullitta, S.; 1989. Improvement techniques and erosion of hillside pasturelands, Rivista di agronomia, 23/4, 372-377 (in Italian).

Robichaud, P.R.; Brown, R.E.; 2002, Silt Fences: An economical technique for measuring hillslope soil erosion,.USDA Forest Service Gen. Tech, Rep., RMRS - GTR - 94.

Robichaud, P.R.; Elliot, W.J.; Pierson, F.B.; Hall, D.E.; Moffet, C.A.; 2007a. Predicting postfire erosion and mitigation effectiveness with a web-based probabilistic erosion model. Catena 71: 229241

Robichaud, P.R.; Elliot, W.J.; Pierson, F.B.; Hall, D.E.; Moffet, C.A.; Ashmun, L.E.; 2007b. Erosion Risk Management tool (ERMIT) Manual (version 2006.01.18),USDA, RMRS, General Technical Report RMRS-GTR-188,31 p.

Robichaud, P.R.; Wagenbrenner, J.W.; Brown, R.E.; Wohlgemuth, P.M.; Beyers, J.L.; 2008. Evaluating the effectiveness of contour-felled log erosion barriers as a post-fire runoff and erosion mitigation treatment in the western United States. International Journal of Wildland Fire. 17: 255273.

Scott, D.F.; Curran, M.P.; Robichaud, P.R.; Wagenbrenner, J.W. 2009. Soil erosion after forest fire. In: Cerdà, A.; Robichaud, P.R., eds. Fire effects on soils and restoration strategies. Enfield, NH: Science Publishers: 178-195.

Shakesby, R.A. Post-wildfire soil erosion in the Mediterranean: Review and future research directions, 2011. Earth-Science Reviews 105: 71-100.

Shakesby, R.A.; Coelho, C.O.A.; Ferreira, A.D.; Terry, J.P.; Walsh, R.P.D.; 1993. Wildfires impacts on soil erosion and hydrology in wet Mediterranean forest, Portugal. Int. J. Wildland Fire 3-2., 95110.

Vacca, A.; Loddo, S.; Ollesch, G.; Puddu, R.; Serra, G.; Tomasi, D.; Aru, A. 2000. Measurement of runoff and soil erosion in three areas under different land use in Sardinia, Italy. Catena 40: 69-92. 